\title{
İlkokul Öğrencilerinin Çevre Kirliliğine İlişkin Görüşleri
}

\section{Gökhan UYANIK*}

Öz: $\mathrm{Bu}$ araştırmanın amacı, ilkokul üçüncü sınıf öğrencilerinin çevre kirliliğine ilişkin görüşlerinin belirlenmesidir. Araştırmada, nitel araştırma yöntemlerinden olgubilim deseni kullanılmıştır. Araştırmanın çalışma grubu, 2016-2017 eğitim-öğretim yılı bahar döneminde Kastamonu İli’nde yer alan biri köy ve biri il merkezinde olmak üzere 2 devlet okulunda ilkokul üçüncü sınıf düzeyinde öğrenim görmekte olan toplam 22 öğrenciden oluşmaktadır. Araştırmanın çalışma grubunun belirlenmesi amacıyla, seçkisiz olmayan örnekleme yöntemlerinden tabakalı amaçlı örnekleme kullanılmıştır. Araştırmada veriler, öğrencilere yöneltilen dört adet açık uçlu soru üzerinden bireysel ve yarı yapılandırılmış görüşmeler aracılığıyla toplanmıştır. Elde edilen veriler ise içerik analizi tekniği ile çözümlenmiştir. Araştırmanın bulgularına göre köy okulunda öğrenim görmekte olan öğrencilerin neredeyse tamamı çevrenin canlı varlıklardan oluştuğunu belirtirken merkez okuldaki öğrenciler çevrenin canlı ve cansız varlıkların bir arada bulunduğu yer olduğunu ifade etmişlerdir. Köy ve merkez okuldaki öğrenciler çevre kirliliği olarak sıklıkla atık çöpler ifadesini kullanmışlardır. Buna ek olarak araba egzozları ile bacalardan kaynaklanan hava kirliliğinden bahsetmişlerdir. Merkez okuldaki öğrenciler araba egzozlarından çıkan dumanlardan bahsederken, köy okulu öğrencileri daha çok evlerinin bacalarından çıkan dumanlardan söz etmişlerdir. Hem köy okulundaki hem de merkez okuldaki öğrenciler çevre kirliliğine sebep olan en önemli etkenin ise insan olduğunu belirtmişlerdir. Çevre kirliliğinin önlenebilmesi için de öncelikle insanların bilinçlendirilmesi gerektiğini vurgulamışlardır.

\footnotetext{
* Kastamonu Üniversitesi, Eğitim Fakültesi Temel Eğitim Bölümü, Sınıf Eğitimi ABD. guyanik@kastamonu.edu.tr, ORCID NO: 0000-0002-5653-6475
} 
Anahtar Kelimeler: Çevre, çevre kirliliği, ilkokul öğrencileri

\section{Opinions towards Environmental Pollution of Primary School Students}

Abstract:The aim of this research is to determine the opinions of the third grade students in primary school on the concept of environment environmental and pollution. The study was a qualitative study of student's ideas about environment and environmental pollution. The participants of the study were $223^{\text {th }}$ grade student from 2 different schools in Kastamonu. While one of the schools where the research is conducted takes place in a village, the other is located in the province center. Data were gathered by semi-structured interviews consisted of 4 open-ended questions. The content analysis technique was applied in the analysis of data. According to the findings of the research, almost all of the students in the village school stated that the encounters were made from living creatures, whereas the students in the central school stated that the surrounding area is where living and non-living assets coexist. The students in the village and the central school frequently used waste garbage expressions as environmental pollution. In additionto this, they talked about air pollution from car exhausts and chimneys. While the students in the central school refer to fumes from car exhausts, the village school students refer more to the fumes from their homes' floors. Both students in the village school and the central school stated that the most important factor causing environmental pollution is human. They also emphasized that people should be made aware of environmental pollution firstly. In addition, they stated that the number of trash cans in the surrounding area should be increased.

Keywords: Environment, environmental pollution, primary school students 


\section{GíRiş}

İnsanoğlu, doğal denge olarak nitelendirilen sağlıklı bir ortamda uzun bir süre hava, su ve toprak gibi temel kaynaklardan sorunsuz olarak yararlanmıştır. Ancak günümüzde hızlı nüfus artışı ve teknolojideki gelişmelerin bir sonucu olarak ortaya çıkan mekân, enerji ve ham maddeye olan ihtiyaç, doğal ortamlardan ve kaynaklardan çok fazla yararlanmayı zorunlu hale getirmiştir (Kahyaoğlu ve Kaya, 2012). Yaşanan çevre sorunlarının çeşitliliği ve boyutları dikkate alındığında; günümüzde endüstri ve teknoloji alanında meydana gelen hızlı gelişmeler, yaşam düzeyinin yükselmesini sağlarken, diğer yandan da doğal dengenin bozulması, kaynakların yok edilmesi ve canlıların yaşamını tehdit eden bir durumun oluşması sonucunu doğurmuştur (Mutlu ve Tokcan, 2012). Bu anlamda çevre kirliğinin, günümüz dünyasının en önemli sorunlarından biri olduğu düşünülmektedir. Çevrenin de kendi kendine kirlenmesi düşünülemez. Çevrenin kirlenmesinde etkisi olan en önemli faktörlerden biri insanoğludur. Bireylerin çevreye karşı duyarlı olmalarının, çevre sorunlarına karşı bilinçli davranmalarının çevre kirliliğinin önlenmesinde en önemli adım olduğu düşünülmektedir. Gelecek nesillere daha sağlıklı ve güvenli bir çevre bırakmak için; çevre kirliliğine sebep olan etkenlerin önlenmesi için başta öğrenciler olmak üzere tüm insanların bu konularda çevre eğitimi yardımıyla bilinçlendirilmesi gerekmektedir. Aksi hâlde çevre sorunları çok daha büyük boyutlara gelebilecektir. Bunun sonucunda da çevre kirliliğii; insanlarla beraber tüm canlıların geleceğini tehdit edecek boyutlara ulaşacaktır (Mutlu ve Tokcan, 2012). Çevrenin bugün geldiği olumsuzluklardan ve çevre sorunlarından kurtulması, insanların çevreye karşı mevcut bakış açılarının değiştirilmesi ile gerçekleşebilir (Çimen ve Yılmaz, 2014). Bu da etkili ve verimli bir çevre eğitimi ile mümkün olabilecektir.

Çevre eğitimi, bireylere çevreleri hakkında bilgi, bilinç, değer ve beceriler ile birlikte çevre sorunlarını çözüme kavuşturmak amacıyla harekete geçme kararlılığını da 
kazandırabilecek bir süreçtir (Kahyaoğlu ve Kaya, 2012). Çevre eğitimi süreci, çevre ile ilgili olaylara yönelik farkındalığın artmasını ve çevre sorunlarının çözümü için gerekli davranışların kazanılmasını sağlamaktadır (Milton, Cleveland \& Bennett-Gates, 1995). Çevre sorunlarının olumsuz etkilerinin ortadan kaldırılması için de etkili bir çevre eğitimine ihtiyaç duyulmaktadır.

Toplumsal açıdan bakıldığında da yaşam koşulları, bireylere küçük yaşlardan itibaren verilecek çevre eğitimini gün geçtikçe gerekli hale getirmektedir. Şöyle ki, küçük şehirlerden, büyük şehirlere göç son 40 yılda büyük bir artış göstermiştir. Bu durum, büyük şehirlerdeki yerleşim alanlarının artmasına, bununla birlikte verimli tarım arazilerinin azalmasına, ormanların tahrip edilmesine, tarımsal üretimin düşmesine, yer altı ve yer üstü kaynakların kirlenmesine neden olmaktadır (Güngördü, 2002). Çocukların yakın çevrelerinde yer alan yeşil alanlar ile birlikte hayvan ve bitki çeşitliliği de giderek azalmaktadır. Hâlbuki yapılan çalışmalar, çocukların yakın çevrelerinde hayvan türlerinin az oluşunun, çocukların hayvanlarla etkileşimde bulunmamasının, onların biyolojik çeşitliliğin önemini ve çevre sorunlarını anlamakta zorlandıklarını ortaya koymuştur (Heywood, 1995; Weilbacher, 1993; Akt. Gülay, 2011). Doğa ile düzenli olarak etkileşime girmeyen, doğal ortamdan uzakta büyüyen çocukların, çevre okuryazarlık becerilerini geliştirme açısından risk altında oldukları belirtilmektedir (Bixler, Carlisle, Hammitt \& Floyd, 1993; Akt. Gülay, 2011). Bu açıdan, çocukların hayvanlarla, bitkilerle, toprakla etkileşim içinde olması hem çevreyi tanımalarını hem de çevreyi koruma açısından duyarlılık kazanmalarını sağlayacaktır.

Teknolojinin gelişmesiyle birlikte içinde yaşadığımız çağda makinelerle geçirilen vakit ve insanların kullandığı makine sayısında önemli miktarda artış vardır. Artık çocuklar ve gençler, iki-üç kuşak önceki nesle göre doğal çevrede ve doğal ortamlarda daha az zaman geçirmektedirler. Artık doğal ortamların yerini sıklıkla yapay ortamlar almaktadır. Hızlı 
şehirleşme ve yeşil alanların azalması, çocukların oyun alanlarını da azaltmıştır (Turgut ve Yılmaz, 2010). Oyun alanları azalan çocuklar da haliyle yapay ortamlarda oynamaya başlayarak, bir bakıma doğal çevreden uzaklaşmış olmaktadırlar. Bireyler, değişen yaşam koşulları içerisinde kalabalık toplumlarda ancak daha büyük bir yalnızlıkla yaşamlarını devam ettirmektedirler. Bu toplum profilinde dünyaya gelen çocuklar ise yalnızlık ve teknolojideki hızlı gelişme ile büyümektedirler. Toplumdan ve çevreden soyutlanma ile kalabalıklar içerisinde yalnız olma sorunu, yüzyılın üstü örtülü tehlikeleri arasında yer almaktadır (Gülay, 2011). Bu üstü örtülü tehlikelerden korunabilmek için de bireylerin çevresel farkındalıklarının olması gerekmektedir. Çevresel farkındalığa sahip olmanın, günümüz insanlarının hepsinde bulunması gereken bir özellik olduğu söylenebilir. Ancak bu sayede çevreye karşı daha duyarlı olarak çevrenin olumsuz etkenlerden korunması sağlanabilecektir. İnsanların çevreye yönelik duyarlılık ve çevresel farkındalık kazanmaları da okullarda verilecek çevre eğitimi ile mümkün olabilir (Çimen ve Yılmaz, 2014; Uyanık, 2016a). Eğitim-öğretim sisteminde yer alan öğretim programları incelendiğinde, çevre ile ilgili kazanımların ilkokul döneminden itibaren verilmeye başlandığı görülmektedir. Bu anlamda, ilkokul çağından itibaren bireylerin çevre ve çevre sorunlarına yönelik farkındalıklarının oluşmaya başladığı söylenebilir. Buradan hareketle, bu araştırmada ilkokul üçüncü sınıf öğrencilerinin çevre ve çevre kirliliğine ilişkin görüşleri alınmış ve bu konularda neler düşündükleri tespit edilmeye çalışılmıştır.

İlgili literatür incelendiğinde ilkokul üçüncü sınıf öğrencilerinin çevre kirliliğine ilişkin görüşlerinin incelendiği çalışmaların sınırlı sayıda olduğu tespit edilmiştir. Yapılan bu çalışmanın da ilgili literatürde yer alan boşluğun doldurulmasına katkı sağlaması bakımından önemli olduğu düşünülmektedir. Buradan hareketle bu araştırmanın amacı, ilkokul üçüncü 
sınıf öğrencilerinin çevre kirliliğine ilişkin görüşlerini incelemektir. Bu amaç doğrultusunda aşağıdaki alt problemlere cevap aranmıştır:

1. Çevre kelimesi öğrencilerde neyi çağrıştırmaktadır?

2. Öğrenciler çevre kirliliğini nasıl tanımlamaktadırlar ve çevre kirliliğine yönelik ne tür örnekler vermektedirler?

3. Öğrencilere göre göre çevre kirliliğinin sebepleri nelerdir?

4. Öğrenciler çevre kirliliğinin önlenmesine yönelik ne tür öneriler sunmaktadırlar?

\section{Yöntem}

\section{Araştırmanın Modeli}

$\mathrm{Bu}$ araştırmada nitel araştırma yöntemlerinden olgubilim deseni kullanılmıştır. Olgubilim (fenomenoloji) deseni, farkında olduğumuz ama derinlemesine ve ayrıntılı bir anlayışa sahip olmadığımız olgulara odaklanmaktadır (Şimşek ve Yıldırım, 2006). Olgular, yaşadığımız dünyada olaylar, deneyimler, algılar, yönelimler, kavramlar ve durumlar gibi farklı biçimlerde karşımıza çıkabilmektedir. (Yıldırım ve Şimşek, 2005). Bu araştırmada da öğrencilerin yaşadıkları ortamlarda karşılaştıkları çevre sorunlarına ilişkin görüş ve düşünceleri alınmıştır. Bu şekilde öğrencilerin farkında oldukları durumların derinlemesine ve ayrıntılı bir biçimde ortaya çıkarılması amaçlanmıştır.

\section{Çalışma Grubu}

Araştırmanın çalışma grubu, 2016-2017 eğitim-öğretim yılı bahar döneminde Kastamonu İli'nde yer alan 2 devlet okulunda ilkokul üçüncü sınıf düzeyinde öğrenim görmekte olan toplam 22 öğrenciden oluşmaktadır. İlgili literatür incelendiğinde ilkokul 
üçüncü sınıf öğrencilerinin çevre kirliliğine ilişkin görüşlerinin araştırıldığı çalışmaların sayıca az olduğu belirlenmiştir, bu nedenle bu araştırma ilkokul üçüncü sınıf öğrencileri ile yürütülmüştür. Araştırmanın gerçekleştirildiği okullardan biri merkeze bağlı bir köyde yer alır iken, diğeri il merkezinde yer almaktadır. Araştırmanın çalışma grubu, seçkisiz olmayan örnekleme yöntemlerinden tabakalı amaçsal örnekleme ile belirlenmiştir. Araştırmaya köy okulunda üçüncü sınıftaki 16 öğrenciden gönüllü 11 öğrenci, il merkezinde yer alan okuldaki üçüncü sınıfta öğrenim gören 34 öğrenciden de gönüllü 11 öğrenci katılmıştır. Köy okulundaki 11 öğrencinin 5'i kız ve 6'sı da erkek öğrencilerden oluşmaktadır. Merkezde yer alan okuldaki görüşme yapılan 11 öğrencinin ise 6'sı k1z ve 5'i erkek öğrencilerden oluşmaktadır. Bu sayılara bakılarak, çalışma grubunda yer alan öğrencilerin cinsiyet değişkeni bakımından dengeli bir dağılım gösterdiği görülmektedir.

\section{Veri Toplama Aracı ve Verilerin Toplanması}

$\mathrm{Bu}$ araştırmada veri toplama aracı olarak araştırmacı tarafından hazırlanan, 4 adet açık-uçlu sorudan oluşan yarı-yapılandırılmış görüşme formu kullanılmıştır. Görüşme formunun geliştirilmesi aşamasında, ilkokul üçüncü sınıf öğrencilerinin çevre ve çevre sorunlarına yönelik görüşlerini incelemek amacıyla ilgili literatürden yararlanılarak, toplamda 8 adet açık-uçlu sorudan oluşan taslak görüşme formu hazırlanmıştır. Görüşme formunun geliştirilmesinde konu ile ilgili yapılan araştırmalar incelenmiş, fen ve çevre bilimi alanında uzman 4 öğretim üyesinin görüşleri alınmıştır. Görüşme formunun geliştirilmesi aşamasında 5 ilkokul üçüncü sınıf öğrencisi ile pilot uygulama olarak görüşme yapılmış ve formda yer alan soruların açıklık ve anlaşılırlık durumu incelenmiştir. Yapılan pilot uygulama ve uzman görüşleri neticesinde, formda yer alan 8 sorudan dördünün içerikle uyuşmadığı tespit edildiği için formdan çıkarılmasına karar verilmiştir. 1 soru üzerinde ise anlaşılırlık düzeyinin 
kolaylaşması bakımından düzenleme yapılmıştır. Bu şekilde veri toplama aracının geçerlik düzeyi artırılmıştır. Sonuç olarak 4 adet açık-uçlu sorudan oluşan görüşme formuna nihai şekli verilmiştir.

Uygulama kapsamında her bir öğrenci ile yapılan görüşme yaklaşık 10 dakika sürmüştür. Yapılan görüşmelerde öğrencilerin sorulara ilişkin görüşleri ses kayıt cihazı ile kayıt altına alınmış ve sonrasında araştırmacı tarafından yazıya dönüştürülerek kaydedilmiştir.

\section{Verilerin Analizi}

$\mathrm{Bu}$ araştırmada ilkokul üçüncü sınıf öğrencilerinin çevre kirliliğine ilişkin görüşleri nitel analiz yöntemi ile tespit edilmiştir. Bu doğrultuda toplanan verilerin analizinde içerik analizi yöntemi kullanılmıştır. İçerik analizinde temelde yapılan işlem, birbirine benzeyen verileri belirli kavramlar ve temalar çerçevesinde bir araya getirmek ve bunları okuyucunun anlayabileceği bir biçimde düzenleyerek yorumlamaktır (Şimşek ve Yıldırım, 2006).

Verilerin analizinde öğrencilerin çevre ve çevre kirliliğine ilişsin görüşleri incelenerek, her soru için konu ile ilgili olan anahtar kavramlar belirlenmiştir. Bu kavramlar araştırmacı tarafından kodlanmıştır. Anahtar kavramların kodlanmasının ardından kodların sınıflandırması yapılmıştır. Kodların sınıflandırılması esnasında araştırmacı dışında bir uzmandan da destek alınmıştır. Bu şekilde sonuçların güvenirliği artırılmıştır. İçerik analizi sonucunda elde edilen veriler tablolarda düzenlenerek betimsel bir şekilde sunulmuştur. Raporlaştırma işleminde öğrencilerin doğrudan görüşlerine yer verilmiş ve çalışmaya katılan katılımcıların gizliliğinin sağlanması amacıyla her bir öğrenciye simge (Ö1, Ö2 vb.) verilmiştir. 


\section{Bulgular}

Öğrencilerle yapılan görüşmelerde ilk soru olarak "Çevre kelimesini duyduğunuzda aklınıza gelenler nelerdir? sorusu sorulmuştur. $\mathrm{Bu}$ soru ile öğrencilerin çevreye ilişkin algılarının belirlenmesi amaçlanmıştır. Çevre kelimesinin onlarda neleri çağrıştırdığı ortaya çıkarılmaya çalışılmıştır. Köy okulundaki 11 öğrenciden 9'u çevre kelimesini duyduğunda aklına hem canlı hem de cansız öğelerin geldiğini ifade etmiştir (ağaçlar, ormanlar, çiçekler, kediler, inekler, koyunlar, köpekler, fareler, tarlalar, bahçeler, evler, motorlu taşıtlar, camiler vb...), 2 öğrenci ise yalnızca canlı öğelerden bahsetmiştir (inekler, köpekler, ağaçlar, çiçekler, kediler, keçiler vb...) . Merkez okuldaki 11 öğrenciden ise 6's1 canlı ve cansız öğelerden birlikte söz etmiştir (evler, fabrikalar, motorlu taşıtlar, parklar, camiler, dükkânlar, okullar, kediler, köpekler, ağaçlar, çimenler, piknik alanları vb...) . 5 öğrenci ise sadece cansız öğelerden söz etmiştir (fabrikalar, dükkânlar, okullar, camiler, motorlu taşıtlar vb...). Bu bulgulara ilişkin frekans ve yüzde değerleri Tablo 1'de görülmektedir.

Tablo 1. Çevre kelimesini duyduklarında ögrencilerin aklına gelen ögeler

\begin{tabular}{|c|c|c|c|}
\hline $\begin{array}{l}\text { Okul } \\
\text { Türü }\end{array}$ & Ögeler & $\mathbf{f}$ & $\%$ \\
\hline \multirow{3}{*}{$\begin{array}{l}\text { Köy } \\
\text { Okulu }\end{array}$} & $\begin{array}{l}\text { Sadece Canlı Ögeler } \\
\text { (inekler, köpekler, ağaçlar, otlar, çiçekler, kediler, keçiler, fareler) }\end{array}$ & 2 & 18,2 \\
\hline & Sadece Cansız Ögeler & 0 & 0 \\
\hline & $\begin{array}{l}\text { Hem Canlı Hem Cansız Ögeler } \\
\text { (ă̆açlar, ormanlar, çiçekler, kediler, inekler, koyunlar, köpekler, } \\
\text { fareler, tarlalar, bahçeler, evler, motorlu tassıtlar, camiler) }\end{array}$ & 9 & 81,8 \\
\hline
\end{tabular}


Sadece Canlı Ögeler

$0 \quad 0$

\begin{tabular}{llrr} 
Merkez & $\begin{array}{l}\text { Sadece Cansı Ögeler } \\
\text { Okul }\end{array}$ & 5 & 45,4 \\
& (fabrikalar, dükkânlar, okullar, camiler, motorlu taşıtlar) & & \\
\cline { 2 - 3 } & $\begin{array}{l}\text { Hem Canlı Hem Cansı Ögeler } \\
\text { (evler, fabrikalar, motorlu taşıtlar, parklar, camiler, dükkânlar, } \\
\text { okullar, kediler, köpekler, ağaçlar, çimenler, piknik alanları) }\end{array}$ & 6 & 54,6 \\
\end{tabular}

Görüşme formunda yer alan birinci soruya öğrencilerin verdikleri cevaplar analiz edildiğinde, köy okulunda öğrenim görmekte olan öğrenciler cevaplarında daha çok canlı ve cansız öğelerden birlikte söz etmişlerdir $(\% 81,8)$. Köy okulundaki öğrencilerin $\% 18,2$ 'si ise sadece canlı ögelerden söz etmiştir. Merkez okulda öğrenim görmekte olan öğrencilerin ise \%54,6's1 hem canlı hem de cansız varlıklardan birlikte söz etmiştir. Merkez okuldaki öğrencileri önemli bir bölümü $(\% 45,4)$ ise sadece cansız varlıklardan bahsetmiştir. Bu durum, cansız varlıkların, merkez okuldaki öğrencilerin hayatlarında önemli bir yere sahip olduğu şeklinde yorumlanabilir.

Köy okulunda öğrenim görmekte olan öğrenciler sıkl1kla orman, tarla, hayvanlar ve bahçelerle ilgili cevaplar verirken, merkez okulda öğrenim gören öğrenciler genellikle evler, motorlu taşıtlar, okullar ve parklar gibi cevaplar üzerinde yoğunlaşmışlardır. Elde edilen bu bulgulara göre, köy okulu ile merkez okulda öğrenim görmekte olan öğrencilerin çevreye ilişkin algılarının farklılık gösterdiği söylenebilir.

Görüşme kapsamında öğrencilere ikinci soru olarak "Size göre çevre kirliliği nedir? Çevre kirliliğine hangi örnekleri verebilirsiniz? soruları yöneltilmiştir. $\mathrm{Bu}$ sorular ile öğrencilerin çevre kirliliğine ilişkin algıları belirlenmeye çalışılmıştır. Öğrencilerin vermiş oldukları cevaplar öncelikle kodlanmış ve sonrasında benzerliklerine göre sınıflanarak temalara ulaşılmıştır. Buna göre iki tema belirlenmiştir. Birinci tema, "insanların neden olduğu kirlilik" diğer tema ise "insanlar ve hayvanların birlikte neden olduğu kirlilik" olarak 
belirlenmiştir. Köy okulunda öğrenim görmekte olan 11 öğrenciden 9'u (\%81,8) “çevre kirliliği nedir" sorusuna, insanların sebep olduğu kirliliktir cevabını vermişlerdir. 11 öğrenciden 2'si $(\% 18,2)$ ise insanlar ve hayvanların birlikte neden olduğu kirlilik olarak görüş bildirmişlerdir. Buna karşın, merkez okulda öğrenim görmekte olan 11 öğrencinin tamamı (\%100) “çevre kirliliği nedir" sorusuna, insanların sebep olduğu kirliliktir cevabını vermişlerdir. Bu verilere ilişkin frekans ve yüzde değerleri Tablo 2'de yer almaktadır.

Tablo 2. Öğrencilerin gözünden çevre kirliliği

\begin{tabular}{llcc}
\hline $\begin{array}{l}\text { Okul } \\
\text { Türü }\end{array}$ & \multicolumn{1}{c}{ Ögeler } & f & \% \\
\hline $\begin{array}{l}\text { Köy } \\
\text { Okulu }\end{array}$ & İnsanların Sebep Olduğu Kirlilik & 9 & 81,8 \\
\cline { 2 - 4 } & İnsanlar ve Hayvanların Birlikte Neden Olduğu Kirlilik & 2 & 18,2 \\
\hline $\begin{array}{l}\text { Merkez } \\
\text { Okul }\end{array}$ & İnsanların Sebep Olduğu Kirlilik & 11 & 100 \\
\cline { 2 - 4 } & İnsanlar ve Hayvanların Birlikte Neden Olduğu Kirlilik & 0 & 0
\end{tabular}

$\mathrm{Bu}$ bulgulara göre, merkez okuldaki öğrencilerin tamamı çevre kirliliğine insanların sebep olduğunu düşünmektedir. Köy okulundaki öğrencilerin de \%81,8’i bu görüşteyken, $\% 18,2$ 'si çevreyi hem hayvanların hem de insanların birlikte kirlettiğinden bahsetmişlerdir. Burada merkez okuldaki öğrencilerden farklı olarak, hayvanların da çevreyi kirlettiğinden söz edilmiştir.

Köy okulunda öğrenim görmekte olan öğrencilere yöneltilen “çevre kirliliğine hangi örnekleri verebilirsiniz" sorusuna verilen cevaplara ilişkin frekans ve yüzde dağılımı Tablo 3'de görülmektedir. 
Tablo 3. Çevre kirliliğine hangi örnekleri verebilirsiniz? sorusuna köy okulu öğrencileri tarafindan verilen cevapların dă̆ılımı

\begin{tabular}{llll}
\hline Kategoriler & Kodlar & f & \% \\
\hline Sanayi Faaliyetlerinden & Fabrika bacalarından çıkan dumanlar & 3 & 27,2 \\
Kaynaklanan & Pil, plastik, naylon atıkları & 7 & 63,6 \\
& Zehirli atıklar & 1 & 9,1 \\
\hline İnsanlardan Kaynaklanan & Araba egzozlarından çıkan dumanlar & 8 & 72,7 \\
& Çöpler & 11 & 100 \\
& Evlerin bacalarından çıkan dumanlar & 10 & 90,9 \\
& Tarımda kullanılan ilaçlar & 4 & 36,3 \\
\hline Sanayi ve İnsanlardan & Akarsuların kirlenmesi & 9 & 81,8 \\
Kaynaklanan & Toprak kirliliği & 6 & 54,5 \\
\hline Hayvanlardan Kaynaklanan & Hayvanların ölüsü & 4 & 36,3 \\
& Hayvanların dışıısı & 3 & 27,2 \\
\hline
\end{tabular}

Tablo 3 incelendiğinde, köy okulunda öğrenim görmekte olan öğrencilerin tamamı (\%100) çevre kirliliğine insanların attıkları çöplerin neden olduğunu ifade etmişlerdir. Buna ek olarak \%91 oranında evlerin bacalarından çıkan dumanların, \%73 oranında egzoz gazlarının ve $\% 36$ oranında da tarım ilaçlarının insanlardan kaynaklanan çevre kirliliği örnekleri olduğunu belirtmişlerdir.

Köy okulundaki öğrencilerin \%64’ü pil, plastik ve naylon atıklarının çevreyi kirlettiğini düşünürken, \%27'sinin fabrika bacalarından çıkan dumanlardan dolayı ve \%9'unun da zehirli atıklardan dolayı çevrenin kirlendiğini düşündüğü tespit edilmiştir. dikkat çeken bir kategori ise hayvanlardan kaynaklanan çevre kirliliği kategorisi olmuştur. Köy okulundaki öğrencilerin \%36'sı hayvanların ölüsünün çevreyi kirlettiğini düşünmektedirler. \%27'si ise hayvanların dışkısından kaynaklı çevre kirliliğinden söz etmişlerdir. Çevre kirliliğine ilişkin köy okulundaki iki öğrencinin vermiş oldukları cevaplar aşağıda yer almaktadır.

Ö1: Insanların yerlere çöp atması yüzünden yerlerin kirlenmesidir. 
Ö2: Evlerimizde yanan sobalardan çıkan dumanlar çevreyi kirletiyor.

Merkez okulda öğrenim görmekte olan öğrencilere yöneltilen “çevre kirliliğine hangi örnekleri verebilirsiniz" sorusuna verilen cevaplara ilişkin frekans ve yüzde dağılımı Tablo 4'de görülmektedir.

Tablo 4. Çevre kirliliğine hangi örnekleri verebilirsiniz? sorusuna merkez okul öğrencileri tarafindan verilen cevapların dă̆ılımı

\begin{tabular}{llll}
\hline Kategoriler & Kodlar & f & \% \\
\hline Sanayi Faaliyetlerinden & Fabrika bacalarından çıkan dumanlar & 10 & 90,9 \\
Kaynaklanan & Pil, plastik, naylon poşet atıkları & 11 & 100 \\
& Zehirli atıklar & 6 & 54,5 \\
& Teknolojinin verdiği zarar & 4 & 36,3 \\
& Petrol atıkları & 2 & 18,1 \\
\hline İnsanlardan Kaynaklanan & Araba egzozlarından çıkan dumanlar & 11 & 100 \\
& Çöpler & 11 & 100 \\
& Evlerin bacalarından çıkan dumanlar & 3 & 27,2 \\
& Gürültü kirliliği & 6 & 54,5 \\
& Parfümlerin fazla kullanılması & 5 & 45,4 \\
\hline Sanayi ve İnsanlardan & Akarsuların kirlenmesi & 7 & 63,6 \\
Kaynaklanan & Toprak kirliliği & 10 & 90,9
\end{tabular}

Tablo 4 incelendiğinde, merkez okulda öğrenim görmekte olan öğrencilerin de tamamı (\%100) çevre kirliliğine insanların attıkları çöplerin neden olduğunu ifade etmişlerdir. Buna ek olarak yine \%100 oranında araba egzozlarından çıkan dumanların, \%54,5 gürültü kirliliğinin, \%45,4 oranında parfümlerin fazla kullanılmasının, \%27,2 oranında da evlerin bacalarından çıkan dumanların insanlardan kaynaklanan çevre kirliliği örnekleri olduğunu belirtmişlerdir.

Merkez okuldaki öğrencilerin \%100’ü pil, plastik ve naylon poşet atıklarının çevreyi kirlettiğini düşünürken, \%90,9'unun fabrika bacalarından çıkan dumanların, \%54,5'inin 
zehirli atıklardan, \%36,3'ünün teknolojiden dolayı ve \%18,1'inin de petrol atıklarından dolayı çevrenin kirlendiğini düşündüğü tespit edilmiştir.

Merkez okuldaki öğrencilerin vermiş olduğu cevaplar incelendiğinde, köy okulundaki öğrencilerden farklı olarak araba egzozlarından çıkan dumanlar, pil, plastik, naylon poşet atıkları, gürültü kirliliği, parfümlerin fazla kullanılması ve teknolojinin verdiği zararlara değindikleri belirlenmiştir. Bu durumun ortaya çıkmasında, kent ve köy yaşamındaki farklı unsurların etkili olduğu düşünülebilir. Çevre kirliliğine ilişkin merkez okuldaki iki öğrencinin vermiş oldukları cevaplar aşağıda yer almaktadır.

Ö3: Her yerde atılmış çöplerin olması, plastik şişeler, cam kırıkları, atılmış kă̆ıtların oluşturduğu kirlilik.

Ö4: Yaşadı̆̆ımız şehirde çok fazla çöp kutusu var ama insanlar çöplerini yerlere atıyor. Bence çevre kirliliği yerlere çöp atılmasıdır.

Öğrencilerle yapılan görüşmelerde üçüncü soru olarak, "Sizce çevre kirliliğinin sebepleri nelerdir? Sorusu yöneltilmiştir. Köy okulunda öğrenim görmekte olan öğrencilerin \%81,8'i çevre kirliliğinin sebebinin insanlar olduğunu ifade etmişlerdir. Köy okulundaki öğrencilerin \%18,2'si ise çevre kirlenmesine hayvanların neden olduğunu belirtmişlerdir. Merkez okulda öğrenim görmekte olan öğrencilerin ise tamamı (\%100) çevre kirliliğinin sebebinin insanlar olduğunu ifade etmişlerdir. Öğrencilerin üçüncü soruya ilişkin cevaplarına yönelik frekans ve yüzde değerleri Tablo 5'de görülmektedir. 
Tablo 5. Öğrencilere göre çevre kirliliğinin sebepleri

\begin{tabular}{llcc}
\hline Okul Türü & & $\mathbf{f}$ & \% \\
\hline Köy Okulu & Çevre kirliliğinin sebebi insanlardır & 9 & 81,8 \\
\cline { 2 - 4 } & Çevre kirliliğinin sebebi hayvanlardır & 2 & 18,2 \\
\hline \multirow{2}{*}{ Merkez Okul } & Çevre kirliliğinin sebebi insanlardır & 11 & 100 \\
\cline { 2 - 4 } & Çevre kirliliğinin sebebi hayvanlardır & 0 & 0 \\
\hline
\end{tabular}

Merkez okuldaki öğrencilerin tamamı insanların çevreye karşı bilinçsiz ve saygısızca davrandığını ifade etmişlerdir. Öğrencilerin bu olumsuzluğun farkında olmaları, geleceğimiz adına sevindirici bir durum olarak değerlendirilebilir. Eğer öğrencilerimiz küçük yaşlardan itibaren çevreye karşı bilinçli olma davranışını kazanırlarsa bu durum ileride çevremizin daha fazla korunmasını sağlayabilecektir.

Görüşme formunda yer alan üçüncü soruda hem köy hem de merkez okulda öğrenim gören öğrencilerin cevapları analiz edildiğinde, çevre kirliliğinin en önemli sebebinin insan faktörü olduğu sonucu ortaya çıkmıştır. Yalnızca köy okulundaki öğrencilerin \%18,2'si ise çevrenin kirlenmesine hayvanların neden olduğunu ifade etmişlerdir. Bu cevabın onların yaşam koşullarından kaynaklandığı söylenebilir.

Öğrencilerle yapılan görüşmede dördüncü soru olarak, “çevre kirliliğini önleyebilmek için neler yapılabilir?” sorusu sorulmuştur. Öğrencilerin verdikleri cevapların incelenmesi sonucunda verilen cevaplar, "insanlara yönelik", "bitki ve hayvanlara yönelik", "zehirli gazlara yönelik" ve "atık maddelere yönelik" başlıkları altında kategorilere ayrılmıştır. Bu soruya hem köy hem de merkez okuldaki öğrencilerin verdikleri cevaplara ilişkin frekans ve yüzde dağılımı Tablo 6'da yer almaktadır. 
Tablo 6. "Çevre kirliliğini önleyebilmek için neler yapllabilir?” sorusuna öğrenciler tarafindan verilen cevapların dă̆llımı

\begin{tabular}{|c|c|c|c|c|}
\hline $\begin{array}{l}\text { Okul } \\
\text { Türü }\end{array}$ & Kategoriler & Kodlar & $\mathbf{f}$ & $\%$ \\
\hline \multirow{11}{*}{$\begin{array}{l}\text { Köy } \\
\text { Okulu }\end{array}$} & \multirow[t]{2}{*}{ İnsanlara Yönelik } & Bilinçlendirme & 8 & 72,7 \\
\hline & & Ceza verme & 4 & 36,3 \\
\hline & Bitki ve & Hayvanları eğitme & 3 & 27,2 \\
\hline & Hayvanlara & Hayvanları koruma & 5 & 45,4 \\
\hline & \multirow[t]{2}{*}{ Yönelik } & Çiçek ve ağaç dikme & 10 & 90,9 \\
\hline & & A ğaçların kesilmemesi & 7 & 63,6 \\
\hline & \multirow{2}{*}{$\begin{array}{l}\text { Zehirli Gazlara } \\
\text { Yönelik }\end{array}$} & Evlerin bacalarına filtre takılması & 7 & 63,6 \\
\hline & & Fabrika bacalarına filtre takılmas1 & 4 & 36,3 \\
\hline & \multirow{3}{*}{$\begin{array}{l}\text { Atık Maddelere } \\
\text { Yönelik }\end{array}$} & Fabrika atıklarının zararsızlaştııılması & 4 & 36,3 \\
\hline & & Yerlere çöp atılmaması & 11 & 100 \\
\hline & & Çevredeki çöp kutularının sayısının artırılması & 6 & 54,5 \\
\hline \multirow{13}{*}{$\begin{array}{l}\text { Merkez } \\
\text { Okul }\end{array}$} & \multirow[t]{3}{*}{ İnsanlara Yönelik } & Bilinçlendirme & 11 & 100 \\
\hline & & Ceza verme & 8 & 72,7 \\
\hline & & Uyarma & 4 & 36,3 \\
\hline & Bitki ve & Hayvanları koruma & 3 & 27,2 \\
\hline & Hayvanlara & Çiçek dikme & 5 & 45,4 \\
\hline & \multirow{2}{*}{ Yönelik } & Ağaçların kesilmemesi & 3 & 27,2 \\
\hline & & Orman varlığını artırma & 4 & 36,3 \\
\hline & \multirow{2}{*}{$\begin{array}{l}\text { Zehirli Gazlara } \\
\text { Yönelik }\end{array}$} & Fabrika bacalarına filtre takı1ması & 11 & 100 \\
\hline & & Araba egzozlarının yenilenmesi & 1 & 9,1 \\
\hline & \multirow{4}{*}{$\begin{array}{l}\text { Atık Maddelere } \\
\text { Yönelik }\end{array}$} & Fabrika atıklarının zararsızlaştııılması & 9 & 81,8 \\
\hline & & Yerlere çöp atılmaması & 11 & 100 \\
\hline & & Çevredeki çöp kutularının sayısının artırılması & 8 & 72,7 \\
\hline & & Denizlere çöp atılmaması & 2 & 18,1 \\
\hline
\end{tabular}

Tablo 6 incelendiğinde, çevre kirliliğinin önlenebilmesi için köy okulunda öğrenim görmekte olan öğrenciler en fazla yerlere çöp atılmaması hususunda (\%100) görüş bildirmişlerdir. Bununla birlikte \%90,9 oranında çiçek ve ağaç dikimi, \%72,7 oranında insanların bilinçlendirilmesi, \%63,6 oranında ağaçların kesilmeyip korunması ve yine \%63,6 oranında bacalara filtre takılması hususunu ifade etmişlerdir. Diğer bir ifade de $\% 54,5$ oranında çevredeki çöp kutusu sayısının artırılması olarak bildirilmiştir.

Merkez okulda öğrenim görmekte olan öğrencilerin tamamı (\%100) çevre kirliliğinin önlenebilmesi için insanların bilinçlendirilmesi gerektiğini ifade etmişlerdir. Bununla birlikte, 
yine merkez okuldaki öğrencilerin tamamı fabrika bacalarına filtre takılması yönünde görüş bildirmişlerdir. Buna ek olarak, merkez okuldaki öğrencilerin \%81,8’i fabrika atıklarının zararsızlaştırılması gerektiğini ifade etmişlerdir. \%72,7’si çevredeki çöp kutusu sayısının artması gerektiğini belirtmiştir. Yine merkez okuldaki öğrencilerin \%72,7'si çevreye zarar veren, çevreyi kirleten insanlara çeşitli cezaların verilmesi gerektiğini belirtmişlerdir.

Köy okulundaki öğrenciler ile benzer şekilde merkez okuldaki öğrencilerin de tamamı (\%100) çevre kirliliğinin önlenebilmesi için yerlere çöp atılmaması gerektiği yönünde görüş bildirmişlerdir.

Merkez okuldaki öğrenciler, köy okulundaki öğrencilerden farklı olarak, "insanların uyarılması", “orman varlı̆̆ının artırılması", "araba egzozlarının yenilenmesi” ve "denizlere çöp atılmaması" hususlarında görüş bildirmişlerdir.

\section{Tartışma ve Sonuç}

$\mathrm{Bu}$ araştırmada köy ve merkez okulda öğrenim görmekte olan ilkokul üçüncü sınıf öğrencilerinin çevre kirliliğine ilişkin görüşlerinin belirlenmesi amaçlanmıştır. Araştırma kapsamında Kastamonu il merkezinde yer alan bir devlet okulu ile Kastamonu iline bağlı bir köy okulundaki öğrencilerin çevre ve çevre kirliliğine ilişkin görüşleri incelenmiştir. Araştırma bulgularına göre, farklı bölgelerde yer alan okullarda öğrenim görmekte olan ilkokul üçüncü sınıf öğrencilerinin çevre ve çevre kirliliğine ilişkin görüşlerinin hem benzerlik hem de farklılıklar içerdiği tespit edilmiştir. Buna göre, köy okulunda öğrenim gören öğrencilerin çevreye ilişkin görüşleri daha çok canlı öğeler içerirken, merkez okulda öğrenim görmekte olan öğrenciler çevrenin canlı ve cansız varlıkların bir arada bulunduğu ortamlardan oluştuğunu ifade etmişlerdir. Hem köy hem de merkez okulda öğrenim görmekte 
olan öğrenciler çevreye ilişkin görüşlerini belirtirken daha çok hayvanlar, bitkiler ve diğer cansız öğelerden (toprak, sınıf, çöp kutuları, evler, binalar, arabalar vb.) bahsetmişler, çevreyi oluşturan öğeler arasında bir canlı varlık olarak insana ise çok az sayıda değinmişlerdir. Bu bulgu, Littledyke (2004) ile Yardımcı ve Bağcı-Kılıç'ın (2010) sonuçları ile benzerlik göstermektedir. Nitekim Yardımcı ve Bağcı-Kılıç (2010) çalışmasında, çocukların çevre algılarını incelemişler ve araştırma sonucu, onların çevreyi daha çok bitkilerden ve hayvanlardan oluşan bir yer olarak algıladıklarını göstermiştir. Çevreyi tanımlarken en az insana yer vermişlerdir. Littledyke’nin (2004) araştırmasında ilköğretim düzeyi öğrencilerinin çevreyi daha çok canlı öğelerden oluşan bir ortam olarak tanımladıkları, insanlara ise bu tanımlar arasında fazla yer vermedikleri belirlenmiştir.

Araştırma sonuçlarına göre hem köy hem de merkez okulda öğrenim görmekte olan öğrencilerin çevre kirliliğine ilişkin görüşleri genel anlamda benzerlik göstermekle birlikte bazı noktalardan birbirinden farklılaşmaktadır. Hem köy hem de merkez okul öğrencileri çevre kirliliği denildiğinde bulundukları ortamların kirliliğinden bahsetmişlerdir. Köy okulu öğrencileri kış aylarında evlerinde soba yandığı için evlerin bacalarından çıkan dumanlardan kaynaklı hava kirliliğinden bahsederken, merkez okulda öğrenim görmekte olan öğrenciler arabaların egzoz gazlarından ve fabrika bacalarından çıkan zehirli gazlardan söz etmişlerdir. $\mathrm{Bu}$ durumun yaşadıkları ortamlardan ve daha çok iç içe oldukları yaşama biçiminden kaynaklandığı söylenebilir. Buna ek olarak hem köy hem de merkez okul öğrencileri, çöplerin oluşturduğu çevre kirliliğine değinmişlerdir. Yaşadıkları çevrede fazla sayıda yerlere atılmış çöplerin olduğundan söz etmişlerdir. Sadık, Çakan ve Artut (2011); Yalçınkaya (2013); Yıldırım ve Bağcı-Kılıç (2010) yapmış oldukları araştırmalarında bu sonuca benzer bulgulara ulaşmışlardır. 
Öğrencilere çevre kirliliğinin sebepleri sorulduğunda ise hem köy hem de merkez okulda öğrenim görmekte olan öğrencilerin neredeyse tamamı, çevre kirliliğine neden olan en önemli unsurun insanlar olduğunu ifade etmişlerdir. Burada köy ve merkez okulu öğrencilerinin görüş olarak farklılaştı̆̆ı bir durum söz konusu olmuştur. Köy okulu öğrencileri çevre kirliliği sebeplerinden bahsederken insanlara ek olarak hayvanlardan da söz etmişlerdir. Köy okulunda öğrenim görmekte olan bazı öğrencilere göre çevre kirliliğinin bir sebebi de hayvanlardır. Bu durumun, köyde yaşayan öğrencilerin yaşadıkları ortamdan kaynaklandığı düşünülebilir.

Öğrencilere çevre kirliliğini önleyebilmek için neler yapılması gerektiği sorulduğunda ise yine hem köy hem de merkez okulda öğrenim görmekte olan öğrencilerin hemen hemen tamamı öncelikle insanların çevre hakkında bilinçlendirilmesi gerektiğini ifade etmişledir. Onlara göre çevre kirliliğinin önlenebilmesi ilk olarak insanların bu konuda bilinçlenmesi ile gerçekleşecektir. Nitekim Ersoy ve Türkkan (2010) da yapmış oldukları çalışmalarında çevre konusunda insanların bilinçlendirilmesi gerektiği görüşlerinin ifade edildiğini belirtmişlerdir. Buna ek olarak ağaçların, çeşitli bitkilerin, ormanlık alanların korunması, fabrika bacalarına filtreler takılması önerilerinde bulunmuşlardır.

Merkez okuldan farklı olarak köy okulunda öğrenim görmekte olan öğrencilerden bazıları, hayvanların eğitilmesi gerektiğine değinmişlerdir. Merkez okuldaki bazı öğrenciler de ulaşımda toplu taşıma araçlarının tercih edilmesi gerektiğine vurgu yapmışlardır. Hem merkez hem de köy okulu öğrencileri çevre kirliği kapsamında en fazla atık çöplerden söz etmişlerdir. Bu çöplerin de çevrelerinde yeterli sayıda çöp kutusunun olmadığından yerlere atılmış olabileceğinden de bahsetmişlerdir. Bu konuda hem köy hem de merkez okulda öğrenim görmekte olan öğrencilerin ortak görüşü, okul bahçesinde, yollarda, kaldırımlarda, duraklarda vb. alanlarda daha fazla çöp kutusu bulundurulması olarak ortaya çıkmıştır. 
Araştırmanın sonuçları genel olarak incelendiğinde köy okulunda öğrenim görmekte olan öğrencilerle merkez okulda öğrenim görmekte olan öğrencilerin çevre ve çevre kirliliğine ilişkin düşünceleri bazı farklılıklar içermektedir. Bu durumun da onların yaşadıkları çevreden, bulundukları ortamlardan kaynaklandığı söylenebilir. Fakat öğrencilerin görüşleri incelendiğinde, bazı noktalarda neredeyse bire bir aynı görüş ve düşüncelerin ortaya çıktığı tespit edilmiştir. $\mathrm{O}$ noktalardan biri de çevre kirliliğinin en büyük sebebinin insanlar olduğudur. Bu anlamda, çevre kirliliğinin önüne geçilebilmesi için öncelikle insanların bu konuda bilinçlendirilmesi gerektiği bir gerekliliktir. Bu da okullarda verilebilecek etkili bir çevre eğitimi ile mümkün olabilir. Bu konuda öğretmenlere önemli sorumluklar düşmektedir. Geleceğin teminatı olan genç nesillerin çevreye ilişkin daha bilinçli davranışlara sahip olması, insanlığın çevreye yönelik bakışında ve çevre sorunlarının çözümünde önemli bir rol oynayacaktır (Uyanık, 2016). Bu anlamda, özellikle küçük yaştaki bireylerden itibaren toplumun her kesiminin çevre ile ilgili derslere ve etkili bir eğitime ihtiyacı olduğu düşünülmektedir. Bu anlamda öğretmenler öncelikle çevreye yönelik kendi davranışları ile öğrencilere olumlu örnek olmak durumundadırlar. Sonrasında ise verecekleri eğitimle öğrencilerini çevreye yönelik olumlu davranışlara yöneltebileceklerdir.

Öğrencilerin çevreye ve çevresel olaylara ilişkin görüşlerinin incelendiği bu tür çalışmaların ilkokul düzeyinde artırılması önerilmektedir. Bundan sonraki çalışmalarda ilkokul kademesinde farklı sınıf düzeylerinde öğrenim görmekte olan öğrencilerin çevre ve çevre kirliğine ilişkin görüşleri araştırılabilir.

\section{Makalenin Bilimdeki Konumu}

Temel Eğitim Bölümü, Sınıf Eğitimi Ana Bilim Dalı 


\section{Makalenin Bilimdeki Özgünlüğü}

Günümüzde çocukların ve gençlerin, çevre kavramına ve çevre sorunlarına ilişkin olumlu bakış açısına sahip olmaları, gelecekte daha yaşanılabilir bir çevreye sahip olunabilmesi adına önemlidir. Bu anlamda, şimdinin küçükleri ve geleceğin büyükleri olan ilkokul öğrencilerinin, çevreye ve çevresel sorunlara karşı duyarlı, bilinçli ve bilgili olmaları vazgeçilmez bir gerekliliktir. Bu ve buna benzer çalışmalarla şimdinin küçükleri geleceğin büyükleri olan ilkokul öğrencilerinin çevre ve çevre kirliliğine ilişkin görüşlerinin araştırılmasının önemli olduğu düşünülmektedir. İlgili literatürde yer alan çalışmalar incelendiğinde ilkokul öğrencileri ile çalışılmış bu türden araştırmaların sayıca az olduğu tespit edilmiştir. Bu araştırmanın hem köy hem de merkez okullarda öğrenim görmekte olan ilkokul üçüncü sınıf öğrencileri ile birlikte yürütülmesi araştırmayı özgün kılan diğer bir etkendir.

\section{Kaynakça}

Çimen, O. ve Y1lmaz, M. (2014). Dönüşümsel öğrenme kuramına dayalı çevre eğitiminin biyoloji öğretmen adaylarının çevre sorunlarına yönelik algılarına etkisi. Bartın Üniversitesi Ĕ̈itim Fakültesi Dergisi, 3(1), 339-359.

Ersoy, A. F. ve Türkkan, B. (2010). İlköğretim öğrencilerinin çizdikleri karikatürlere yansıttıkları sosyal ve çevresel sorunların incelenmesi. Ĕ̌itim ve Bilim, 35(156), 96109.

Gülay, H. (2011). Ağaç yaş iken eğilir: Yaşamın ilk yıllarında çevre eğitiminin önemi. Tübav Bilim Dergisi, 4(3), 240-245. 
Güngördü, E. (2002). Türkiye'de nüfus hareketleri ve şehirleşme. Kastamonu Eğitim Dergisi, $10(2), 409-414$.

Kahyaoğlu, M. ve Kaya, M. F. (2012). Öğretmen adaylarının çevre kirliliğine ve çevreyle ilgili sivil toplum örgütlerine yönelik görüşleri. Ĕgitim Bilimleri Araştırmaları Dergisi Uluslararası e-Dergi, 2(1), 91-107.

Littledyke, M. (2004). Primary children's views on science and environmental issues: Examples of environmental cognitive and moral development. Environmental Education Research, 10(2), 217-235.

Milton, B., Cleveland, E., \& Bennett-Gates, D. (1995). Changing perceptions of nature, self and others: A report on a park/school program. Journal of Environmental Education, 26(3), 32-42.

Mutlu, M. ve Tokcan, H. (2012). İlköğretim 7. sınıf öğrencilerinin toprak kirliliği hakkındaki düşünceleri. Uluslararası Alan Araştırmaları Dergisi, 1(1), 65-75.

Sadık, F., Çakan, H. ve Artut, K. (2011). Çocuk resimlerine yansıyan çevre sorunlarının sosyo-ekonomik farklılıklara göre analizi. İlköğretim Online, 10(3),1066-1080.

Şimşek, H. ve Yıldırım, A. (2006). Nitel Araştırma Yöntemleri. Ankara: Seçkin Yayıncılık.

Turgut, H. ve Yılmaz, S. (2010). Ekolojik temelli çocuk oyun alanlarının oluşturulması. III. Ulusal Karadeniz Ormancılık Kongresi, Artvin Çoruh Üniversitesi, Bildiri Kitabı. 4, 1618-1630, 20-22 May1s 2010.

Uyanık, G. (2016a). Birleştirme tekniğine dayalı öğretimin çevre sorunlarına yönelik tutum akademik başarı ve kalıcılığa etkisi. Turkish Journal of Education, 5(2), 60-71. 
YYÜ Eğitim Fakültesi Dergisi (YYU Journal Of EducationFaculty),2017; 14(1):1574-1600,http://efdergi.yyu.edu.tr

http://dx.doi.org/10.23891/efdyyu.2017.56

ISSN:1305-020

Uyanık, G. (2016b). Öğretmen adaylarının çevre sorunlarına ilişkin bilgi düzeylerinin ve tutumlarının incelenmesi. Online Fen Eğitimi Dergisi, 1(1), 30-41.

Yalçınkaya, E. (2013). İlköğretim 8. sınıf öğrencilerine göre çevre sorunları: Nitel bir çalışma. Marmara Coğrafya Dergisi, 27(1), 416-439.

Yardımcı, E. ve Bağcı-Kılıç, G. (2010). Çocukların gözünden çevre ve çevre sorunları. İlköğretim Online, 9(3), 1122-1136.

Yıldırım, A. ve Şimşek, H. (2005). Sosyal bilimlerde nitel araştırma yöntemleri. Ankara: Seçkin Yayınları. 


\section{Summary}

Problem Statement: When the diversity and dimensions of living environmental problems are taken into consideration; Rapid developments in the field of industry and technology nowadays lead to a rise in the level of life and on the other hand the destruction of natural equilibrium, the destruction of resources and the creation of a situation threatening the life of the living creatures. In this sense, environmental pollution is thought to be one of the most important problems of today's world. It is unthinkable for the self to be polluted. One of the most important factors affecting the pollution of the environment is human. It is believed that the sensitivity of individuals towards the environment is the most important step in preventing environmental pollution by being conscious of environmental problems. This can only be possible with effective and efficient environmental education. Environmental education is a process that can gain the determination of individuals to take action in order to solve environmental problems together with knowledge, awareness, values and skills about the environment. To leave a healthier and safer environment for future generations; it is necessary for all people, especially students, to be conscious of these issues with the help of environmental education in order to prevent environmental pollution. When the related literature is examined, it is determined that the opinions of the primary school students about environmental and environmental pollution are few in number.

Purpose of the Study: The purpose of this study is to examine the opinions of third grade primary school students on environmental and environmental pollution.

Method: In this study, phenomenolgy design was used. Phenomenology design focuses on phenomena that we are aware of but do not have an in-depth and detailed understanding. The phenomena can emerge in different ways in the world we live in, such as events, experiences, perceptions, orientations, concepts and situations. The study group consisted of 22 students 
from 2 primary schools in Kastamonu province during the spring semester of 2016-2017 academic year. While one of the schools where the research is carried out is located in a village connected to the center, the other is located in the center of the province. 11 students from the village school and 11 students from the provincial center participated in the research. Semi-structured interview form consisting of 4 open-ended questions, prepared by the researcher, was used as data collection tool in the research. Content analysis method was used in analysis of collected data.

Findings and Discussions: In the interviews with the students, the first question to them was "What are your thoughts when you hear the environment? The question has been asked. When 9 of the 11 students in the village school heard the words of environment, they expressed that living things and inanimate items came together. 2 students mentioned only live items. 6 of the 11 students in the central school talked about living and non-living items together. 5 students mentioned only lifeless items. It has been found that while the answers of the students who are studying at the village school concentrate more on living things, the students who are studying in the central school regard inanimate assets as a part of the periphery in addition to living things. Within the scope of the interview, the second question to the students was "What is environmental pollution for you? Which samples can you give to environmental pollution?" When the answers given by the students at the central school were examined, it was determined that they were exposed to smoke, battery, plastic, nylon bag waste, noise pollution, excessive use of perfumes and damages caused by technolo- gies. It can be considered that different factors in urban and rural life are influential in the emergence of this situation. As a third question in interviews with students, "What are the reasons for environmental pollution in you?" The third question in interview form, when the answers of students from both village and central school were analyzed, it was revealed that the most 
important cause of environmental pollution was the human factor. Only $28 \%$ of the pupils in the village school stated that the animals were responsible for polluting the environment. It can be said that this answer is due to their living conditions. As a fourth question, the question "What can be done to prevent environmental pollution?" has been asked. Like the students in the village school, all of the students in the central school expressed the opinion that no place should be trashed in order to prevent environmental pollution. Unlike the students in the village school, the students in the central school reported opinions on "warning people," "increasing the number of forests," "renewing car exhausts," and "not throwing garbage in the seas."

Conclusions and Recommendations: In this study, it was aimed to determine the opinions of third grade primary school students in the village and central school about the environment and environmental pollution. According to the findings, it was determined that the opinions of the third grade students at the primary schools attending to the schools in different regions included both the similarities and the differences about the environmental and environmental pollution. Whereas the opinions of the students in the village school about the environment are more lively, the students who are studying in the central school have stated that the environment consists of living and non-living environments together. Students who are studying at both the village and the central school have expressed opinions about the environment rather than mention animals, plants and other inanimate items (earth, class, garbage cans, houses, buildings, cars, etc.) they mentioned very few. It is a necessity for people to be conscious of this issue so that environmental pollution can be prevented. This can be achieved through effective environmental education that can be provided to schools. In this sense, the teachers have to be a positive example for the students with their behavior 
YYÜ Eğitim Fakültesi Dergisi (YYU Journal Of EducationFaculty),2017; 14(1):1574-1600, http://efdergi.yyu.edu.tr

towards the environment. Afterwards, they will be able to direct their students towards positive behaviors towards the environment.

Keywords: Environment, environmental pollution, primary school students 